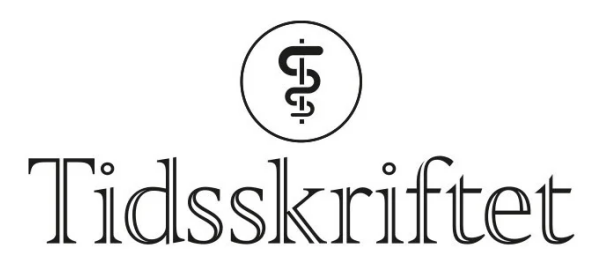

DEN NORSKE LEGEFORENING

\title{
Hvor blir det av alle legene?
}

\section{LEDER}

\section{METTE BREKKE}

mette.brekke@medisin.uio.no

Mette Brekke er spesialist i allmennmedisin og professor ved Avdeling for allmennmedisin, Universitetet i Oslo.

Forfatteren har fylt ut ICMJE-skjemaet og oppgir ingen interessekonflikter.

\section{JEANETTE SOLHEIMSLID BJØRKE}

Jeanette Solheimslid Bjørke er spesialist i psykiatri, overlege ved Klinikk psykisk helsevern voksne, Stavanger universitetssjukehus og ph.d.-stipendiat ved Universitetet i Bergen.

Forfatteren har fylt ut ICMJE-skjemaet og oppgir ingen interessekonflikter.

\section{TORBEN WISBORG}

Torben Wisborg er spesialist i anestesiologi, professor, overlege ved Akuttavdelingen, Finnmarkssykehuset, Klinikk Hammerfest og forskningsleder ved Nasjonal kompetansetjeneste for traumatologi, Oslo universitetssykehus.

Forfatteren har fylt ut ICMJE-skjemaet og oppgir ingen interessekonflikter.

\section{Hvordan kan det ha seg at legemangelen i Norge øker parallelt med at antallet yrkesaktive leger øker?}

Ifølge Legeforeningens tall fra juli i år er antallet yrkesaktive leger under 70 år i Norge 27 924, hvorav 15502 har spesialistgodkjenning (1). Det er en tredobling fra 1985, da antallet var 10 134. For tiden har vi én lege per knapt 200 innbyggere. I Europa er det bare Hellas, Litauen og Østerrike som har høyere legetetthet (므). Medisinstudiet er et av de mest attraktive studiene, og nåløyet for å få en studieplass i Norge er trangt. En gjennomgang av de fire medisinske fakulteters hjemmesider (juli 2021) viser at i år har til sammen 716 begavede, arbeidsomme og dedikerte unge mennesker blitt tilbudt plass. I tillegg har et liknende antall norske studenter startet opp ved et utenlandsk universitet. Burde ikke dette være nok til å dekke befolkningens behov for legetjenester?

Det ser ikke slik ut. Tvert imot er legetjenesten i krise på flere områder. Mest prekært er fastlegekrisen, der den ene kommunen etter den andre rapporterer om at fastlegene slutter og at det er umulig å få tak i nye (3). Mens det for få år siden var små, usentrale kommuner som merket den gryende krisen, sliter man nå med å erstatte fastleger også i større byer over hele landet. «Legebarometeret» slår fast at hele $85 \%$ av kommunene har hatt problemer med å rekruttere fastleger det siste året (4.). Antallet kommuner med store rekrutteringsproblemer har økt med 6oo \% siden 2017 (4). «Fastlegeordningen renner ut mellom fingrene på oss», sa en fortvilet legeforeningspresident i mai (3). Mange deler 
hennes fortvilelse. Også i spesialisthelsetjenesten er det problemer: Det store flertallet av sykehusene forteller om vansker med å rekruttere psykiatere det siste året, med ubesatte stillinger og dårligere pasientbehandling til følge (4). Andre spesialiteter melder også om rekrutteringsvansker og legemangel, inkludert anestesi (5), gynekologi og radiologi (므), og det rapporteres om utstrakt bruk av dyre vikarordninger for å opprettholde et minimumsnivå av helsetjenester.

Så hvor blir alle legene av? En hel del nyutdannede står dessverre i kø for å få tatt sin LIS1tjeneste, før de kan gå i gang med å spesialisere seg (7.). Dette er blitt en uakseptabel flaskehals som fører til at et betydelig antall unge leger blir gående i korte, ikkemeritterende vikariater kanskje i årevis. Når det samtidig er skrikende mangel på leger til å fylle ubesatte stillinger, er dette et paradoks.

\section{"Dagens unge leger aksepterer ikke at legerollen er det som definerer hele deres identitet og familieliv»}

Fremveksten av private legetjenester tapper noe av legetilfanget. De siste årene har antall nordmenn som har tegnet behandlingsforsikring, steget jevnt og trutt, og ved utgangen av 2020 hadde nærmere 650 ooo nordmenn en slik forsikring (ㅁ). Bruken av forsikringene har $\emptyset \mathrm{kt}$ tilsvarende, med en stigning på $9 \%$ bare siden 2019 (ㅁ). Personer uten forsikring bruker også private legetjenester en gang iblant, særlig ved akutte, mindre alvorlige problemer. Kompetente leger trengs for å dekke denne etterspørselen. «Vi har som mål å bli Norges beste arbeidsplass for leger», skriver en av de private aktørene (9), og fremhever at en jobb hos dem innebærer høy grad av fleksibilitet til å dyrke familieliv og hobbyer. Dette står i kontrast til f.eks. en fastlegejobb med personalansvar, store økonomiske investeringer og vaktbelastning.

Her er vi kanskje ved sakens kjerne: Dagens unge leger stiller legitime krav. Vårt inntrykk er at de ikke aksepterer at legerollen er det som definerer hele deres identitet og familieliv. De $\emptyset$ nsker ikke å flytte land og strand rundt. De ønsker ordnede arbeidsforhold, og dette

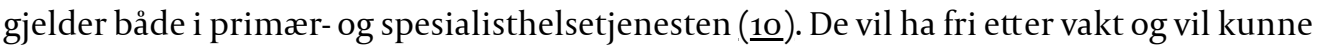
delta på tilvenning $\mathrm{i}$ barnehagen. Både for fastlegeordningen og de fleste sykehusspesialitetene er realiteten milevidt unna dette. Så lenge det er situasjonen, blir det neppe noen løsning på hverken fastlegekrise eller rekrutteringsproblemer på sykehusene.

Beordring, legefordelingsutvalg og lignende reguleringer har ikke ført frem (11). Legeyrket er i endring. For å unngå drenasje av leger til private aktører på bekostning av det offentlige helsevesen må kommuner og helseforetak forstå at de tidligere akseptable arbeidsbetingelsene ikke lenger tiltrekker arbeidstakere. Leger, som tidligere kanskje ble ansett som helter, er en utdøende rase og ikke noe ideal lenger.

\section{LITTERATUR}

1. Den norske legeforening. Om leger i Norge. https://www.legeforeningen.no/omoss/legestatistikk/om-leger-i-norge Lest 5.10.2021.

2. Health in Norway - 2017: Commentary report for OECD comparison of health in different countries. Oslo: Folkehelseinstituttet, 2017. https://www.fhi.no/en/publ/2017/Health-in-Norway-2017/ Lest 5.10.2021.

3. Sæther AS, Nave OB. Legepresidenten: Fastlegeordningen renner ut mellom fingrene på oss. VG 10.5.2021. https://www.vg.no/nyheter/innenriks/i/JJz2a8/legepresidenten-fastlegeordningen-renner-utmellom-fingrene-paa-oss Lest 5.10.2021.

4. Den norske legeforening. Legebarometeret: Rekrutteringskrise blant både fastleger og psykiatere. https://www.legeforeningen.no/nyheter/2021/legebarometeret-rekrutteringskrise-blant-badefastleger-og-psykiatere/ Lest 5.10.2021.

5. Storvik AG. Har avlyst 32 operasjonsdager på seks uker på grunn av mangel på anestesileger. Dagens medisin 28.3.2021. https://www.dagensmedisin.no/artikler/2021/03/28/har-avlyst-32- 
operasjonsdager-pa-seks-uker-pa-grunn-av-mangel-pa-anestesileger/ Lest 5.10.2021.

6. Roksund M. Sykehuset har for få spesialister. NRK 23.7.2014.

https://www.nrk.no/vestfoldogtelemark/legemangel-gir-konsekvenser-1.11841888 Lest 5.10.2021.

7. Helsedirektoratet. Søknad og frister: Antall LIS1-stillinger.

https://www.helsedirektoratet.no/tema/autorisasjon-og-spesialistutdanning/spesialistutdanning-forleger/lis1/soknad-og-frister\#antalllisstillinger Lest 5.10.2021.

8. Finans Norge. Behandlingsforsikring - nok et rekordår.

https://www.finansnorge.no/aktuelt/nyheter/2021/o2/behandlingsforsikring--nok-et-rekordar/ Lest 16.9.2021.

9. Dr. Dropin. Norges beste arbeidsplass for leger. https://drdropin.no/karriere Lest 16.9.2021.

10. Bååthe $\mathrm{F}$, Rosta J, Bringedal $\mathrm{B}$ et al. How do doctors experience the interactions among professional fulfilment, organisational factors and quality of patient care? A qualitative study in a Norwegian hospital. BMJ Open 2019; 9: e026971. [PubMed][CrossRef]

11. Skoglund E. Leger til folket. Tidsskr Nor Legeforen 2013; 133: 1847-50. [PubMed][CrossRef]

Publisert: 8. november 2021. Tidsskr Nor Legeforen. DOI: 10.4045/tidsskr.21.0701

(C) Tidsskrift for Den norske legeforening 2023. Lastet ned fra tidsskriftet.no 26. april 2023. 